\title{
Anti-hypercholesterolemic activity of herbal juice with shelf life of 50 and 100 days in male rats induced by PTU and high-fat diet
}

\section{Aktivitas antihiperkolesterolemia jus herbal masa simpan 50 dan 100 hari pada tikus jantan yang diinduksi PTU dan pakan tinggi lemak}

\author{
Sari Meisyayati ${ }^{*}$, Ade Arinia Rasyad ${ }^{2}$, Frelis Setya Nanda ${ }^{1}$, Ayu Lestari ${ }^{1}$, Alex Ferianto ${ }^{1}$, Rizki \\ Wahyudi ${ }^{1}$
}

1Program Studi S1 Farmasi, STIFI Bhakti Pertiwi, Palembang, Indonesia

2Program Studi D3 Farmasi, STIFI Bhakti Pertiwi, Palembang, Indonesia

*Corresponding author: sari.meisyayati@gmail.com

\begin{abstract}
Background: Herbal juice with the composition of rosella flower, garlic, red ginger, dan lime extract, apple cider vinegar and honey has been proven to be effective as an anti-hypercholesterolemia and has a high level of safety through acute and sub chronic toxicity tests that have been carried out. To be marketed, it is also necessary to know how long this herbal juice formula preserve its antihyperlipidemic effect during the storage process.

Objective: This study was aimed to examine the effectiveness of herbal juice stored for 50 days and 100 days in PTU-induced rats and high-fat diet.

Methods: This test used 6 groups of animals consists of group I (Na CMC 0.5\%/negative control), group II (fresh herbal juice), group III (herbal juice stored 50 days at room temperature), group IV (herbal juice stored for 50 days at cold temperatures), group V (herbal juice stored for 100 days at room temperature), and group VI (herbal juice stored for 100 days at cold temperatures). The dosage of the test preparation was $5.4 \mathrm{ml} / \mathrm{kg}$ given once a day for 10 days. Induction was carried out using PTU ad libitum and high-fat diet twice a day for 10 days. Measurement of serum total cholesterol levels was carried out on day 0 and 11 using the CHOD-PAP method. Results: Groups II and IV could reduce cholesterol significantly compared to the negative control group $(\mathrm{p}<0.05)$, while the other groups could increase blood cholesterol level.

Conclusion: Herbal juice showed effectiveness as anti-hypercholesterolemia in male white rats after being stored for 50 days and 100 days. Shelf life and temperature do not reduce its activity.

Keywords: anti-hypercholesterolemia, herbal juice, shelf life, temperature

\section{Intisari}

Latar belakang: Jus herbal dengan komposisi sari bunga rosella, bawang putih, jahe merah, jeruk nipis, cuka apel dan madu telah terbukti efektif sebagai antihiperkolestrolemia dan memiliki tingkat keamanan yang tinggi melalui uji toksisitas akut dan subkronik yang telah dilakukan. Untuk dapat dipasarkan, perlu pula diketahui seberapa lama formula jus herbal ini mampu mempertahankan efek antihiperlipidemianya selama proses penyimpanan

Tujuan: Penelitian ini bertujuan untuk mengkaji efektivitas jus herbal yang disimpan 50 hari dan 100 hari pada tikus yang diinduksi PTU dan pakan tinggi lemak.

Metode: Pengujian ini menggunakan 6 kelompok hewan perlakuan yang terdiri dari kelompok I (NaCMC 0,5\%/kontrol negatif), kelompok II (jus herbal segar), kelompok III (jus herbal yang disimpan 50 hari suhu kamar), kelompok IV (jus herbal yang disimpan 50 hari suhu dingin), kelompok V (jus herbal yang disimpan 100 hari suhu kamar), dan kelompok VI (jus herbal yang disimpan 100 hari suhu dingin). Dosis sediaan uji 5,4 $\mathrm{ml} / \mathrm{kgbb}$ yang diberikan satu kali sehari selama 10 hari. Induksi dilakukan dengan pemberian PTU ad libitum
\end{abstract}


dan pakan tinggi lemak 2x sehari selama 10 hari. Pengukuran kadar kolesterol total serum dilakukan pada hari ke-0 dan ke-11 dengan metode CHOD-PAP.

Hasil: Kelompok II dan IV dapat menurunkan kolesterol secara signifikan dibandingkan kelompok kontrol negatif $(\mathrm{p}<0,05)$, sementara kelompok lain mengalami peningkatan kadar kolesterol darah.

Kesimpulan: Jus herbal menunjukkan efektivitas sebagai antihiperkolesterolemia pada tikus putih jantan setelah disimpan selama 50 hari dan 100 hari. Masa simpan dan suhu tidak mengurangi aktivitasnya.

Kata kunci : antihiperkolesterolemia, jus herbal, masa simpan, suhu

\section{Pendahuluan}

Penyakit kardiovaskular merupakan penyebab kematian nomor satu secara global. Ada sekitar 17,9 juta jiwa terenggut akibat penyakit ini. Empat dari lima kematian akibat penyakit kardiovaskular disebabkan karena serangan jantung dan stroke (WHO, 2020). Di Indonesia, menurut laporan Riset Kesehatan Dasar yang dilakukan oleh Balitbangkes pada tahun 2018, terdapat 7,6\% dari penduduk Indonesia yang memiliki kadar kolesterol yang tinggi dan 21,2\%nya memiliki kadar kolesterol pada ambang batas (Kemenkes, 2019).

Terdapat hubungan yang sangat kuat antara kejadian penyakit kardiovaskular dengan kondisi hiperlipidemia yang dapat berujung dengan kematian (Murphy et al., 2012). Tingginya kadar kolesterol, terutama LDL akan menyebabkan penumpukan di pembuluh darah sehingga terjadi penyempitan serta dinding pembuluh darah menjadi kaku. Hal ini yang menyebabkan penyakit kardiovaskuler, seperti hipertensi, stroke, dan serangan jantung. Oleh karena itu, menjaga kadar lipid darah agar tetap dalam rentang normal merupakan salah satu tindakan yang harus dilakukan.

Pencarian alternatif obat antihiperlipidemia giat dilakukan mengingat efek samping penggunaan obat-obat antihiperlipidemia yang sudah ada. Berdasarkan hasil penelitian yang dilakukan oleh Upia (2017), Risa (2017), Herpi (2017) serta Hera (2017) diperoleh informasi bahwa terdapat sejumlah formula jus herbal yang mampu menurunkan kadar kolesterol total, darah hewan percobaan. Dari sejumlah formula tersebut terdapat satu formula yang menunjukkan efek antihiperlipidemia terbesar yaitu formula jus herbal yang mengandung sari bunga rosella, bawang putih, jahe merah, jeruk nipis, cuka apel dan madu. Formula ini juga telah dilakukan uji toksisitas akutnya dan menunjukkan nilai $\mathrm{LD}_{50}$ yang berada pada tingkatan toksisitas yang masuk kategori praktis tidak toksik sehingga memiliki nilai keamanan yang tinggi untuk digunakan (Fitriani, 2018). Formula tersebut juga telah diuji toksisitas subkronisnya pada ginjal dan hasilnya tidak terjadi peningkatan kadar kreatinin dan urea (BUN) pada serum tikus dan menunjukkan histopatologi yang normal (Tornado, 2019).

Berdasarkan hasil sejumlah penelitian tersebut maka formula jus herbal tersebut berpotensi untuk dimanfaatkan secara meluas oleh masyarakat dan dapat pula dipasarkan oleh industri rumah 
tangga. Untuk dapat dipasarkan secara meluas, perlu pula diketahui seberapa lama formula jus herbal ini mampu mempertahankan efek antihiperlipidemianya selama proses penyimpanan sehingga ketika sediaan ini dimanfaatkan oleh masyarakat masih menunjukkan efektifitas sebagai anti hiperlipidemia. Oleh karena itu, dilakukan penelitian untuk menguji efektivitas jus herbal yang mengandung sari bunga rosella, bawang putih, jahe merah, jeruk nipis, cuka apel dan madu dengan masa simpan 50 hari dan 100 hari di suhu ruangan dan suhu lemari pendingin terhadap kolesterol pada tikus jantan yang diinduksi PTU dan pakan tinggi lemak.

\section{Metode}

\subsection{Alat dan bahan}

Alat yang digunakan yakni restrainer tikus, panci kaca (Luminarc®), slow Juicer EJ-C20Y-RD (Sharp ${ }^{\circledR}$ ), sentrifuge (Hettick ${ }^{\circledR}$ ), dan semi auto chemistry analyzer (SHM Diagnostik®). Bahan yang digunakan dalam penelitian ini yakni bunga rosella, bawang putih, jahe merah, jeruk nipis, cuka apel (Tahesta ${ }^{8}$ ), Madu SNI (Kembang Joyo ${ }^{8}$ ), Na CMC(Brataco), PTU, dan pakan tinggi lemak.

\subsection{Hewan percobaan}

Sebanyak 36 ekor tikus galur Wistar jantan dengan kondisi sehat usia 6-8 minggu dengan bobot 150 g-200 g diambil secara acak dan diaklimatisasi selama 7 hari dengan diberi akses bebas terhadap makanan dan minuman yang cukup. Pada akhir pengujian seluruh hewan dikorbankan menggunakan n-heksan.

\subsection{Pembuatan dan penyimpanan jus herbal}

Masing-masing bahan herbal, terkecuali cuka apel dan madu, dicuci bersih terlebih dahulu sebelum diambil sarinya menggunakan slow juicer. Selanjutnya seluruh sari bahan herbal dimasukkan ke dalam panci kaca sesuai jumlah yang dibutuhkan (Tabel 1). Kemudian dilakukan pemanasan selama 5 menit pada suhu $60-70^{\circ} \mathrm{C}$ untuk selanjutnya dilakukan pendinginan pada suhu kamar. Campuran tersebut kemudian ditambahkan dengan cuka apel dan madu lalu diaduk homogen.

Tabel 1. Formula jus herbal

\begin{tabular}{lc}
\hline \multicolumn{1}{c}{ Komposisi } & Jumlah \\
\hline Sari bunga rosella & $20 \mathrm{ml}$ \\
Sari bawang putih & $10 \mathrm{ml}$ \\
Sari jahe merah & $30 \mathrm{ml}$ \\
Sari jeruk nipis & $10 \mathrm{ml}$ \\
Cuka apel & $10 \mathrm{ml}$ \\
Madu & $\mathrm{ad} 150 \mathrm{ml}$ \\
\hline
\end{tabular}

Seminar Nasional Asosiasi Perguruan Tinggi Farmasi Indonesia (APTFI) III-Tantangan Pandemik (covid-19) dalam pembelajaran dan penelitian kefarmasian 16-20 Agustus 2021 (Virtual Conference) 
Jus herbal kemudian dimasukkan dalam botol kaca dan ditutup rapat lalu disimpan selama 50 hari dan 100 hari. Tiap masa simpan, jus herbal tersebut disimpan pada 2 suhu yang berbeda yaitu pada suhu kamar $\left(25-30^{\circ} \mathrm{C}\right)$ dan suhu lemari pendingin $\left(4-8^{\circ} \mathrm{C}\right)$. Pada penelitian ini, dibuat pula jus herbal segar tanpa penyimpanan untuk dilakukan pengujian aktivitas antiheperkolesterolemianya.

\subsection{Induksi hiperkolesterolemia}

Pada penelitian ini, induksi hewan uji agar meningkat kadar kolesterol dalam darah menggunakan propiltiourasil (PTU) dan pakan tinggi lemak. PTU dengan dosis 0,01\% b/v diberikan sebagai air minum ad libitum. Pakan tinggi lemak dibuat menggunakan komposisi berupa minyak jelantah: lemak sapi: telur puyuh: Pur 551 dengan perbandingan sebesar 1:1:2:4 yang diberikan 30 g/hari. PTU dan pakan tinggi lemak diberikan 2 kali dalam sehari selama 10 hari bersamaan dengan perlakuan.

\subsection{Uji aktivitas antihiperkolesterolemia}

Penelitian ini menggunakan hewan percobaan sebanyak 36 ekor tikus yang dibagi menjadi 6 kelompok perlakuan. Kelompok I kontrol negatif (NaCMC 0,5\%), kelompok II diberikan jus herbal yang baru dibuat (segar), kelompok III diberikan jus herbal yang sudah disimpan setelah 50 hari pada suhu ruang, kelompok IV diberikan jus herbal dengan masa simpan 50 hari pada suhu dingin, kelompok V diberikan jus herbal masa simpan 100 hari pada suhu ruang, dan kelompok VI diberikan jus herbal dengan masa simpan 100 hari pada suhu dingin. Dosis jus herbal yang diberikan sama, yakni 5,4 ml/kgbb. Semua kelompok diinduksi dengan PTU dan pakan tinggi lemak.

Pengukuran kadar kolesterol total dilakukan pada hari ke-0 sebelum perlakuan dan pada hari ke-11 dengan menggunakan sampel darah tikus yang diambil melalui vena lateral ekor. Pemeriksaan kadar kolesterol total menggunakan metode cholesterol oxidase-peroxidase aminoantypirin (CHODPAP).

\subsection{Analisis data}

Data yang diperoleh dianalisis secara statistik dengan Anova satu arah dan dilanjutkan dengan uji Duncan dengan taraf kepercayaan 95\%.

\section{Hasil dan pembahasan}

Pada penelitian ini dilakukan pengujian efektivitas antihiperkolesterolemia jus herbal yang mengandung sari bunga rosella, rimpang jahe merah, umbi bawang putih, jeruk nipis, cuka apel dan madu yang disimpan selama 50 dan 100 hari pada suhu kamar suhu dingin terhadap tikus putih jantan galur Wistar. Efektivitas tersebut didukung oleh adanya aktivitas antihiperlipidemia dari 
masing-masing komponen yang telah dibuktikan dari sejumlah penelitian. Bawang putih diketahui mampu menghambat enzim squalene monooxygenase dan HMG-CoA reductase (Gebhardt, 1993). Kelopak bunga rosella mampu menurunkan trigliserida serum pasien yang mengalami sindrom metabolik (Asgary et al., 2016). Pada penelitian yang dilakukan oleh Safitri, dkk (2016) diketahui profil lipid serum tikus percobaan yang diberikan ekstrak jahe merah mengalami perbaikan. Begitu pula dengan jeruk nipis yang diketahui mampu menurunkan kolesterol total serum kelinci setelah pemberian selama 4 minggu (Khan et al., 2010) dan cuka apel yang juga mampu menurunkan kadar sejumlah lipid darah (Behesti et al., 2012). Dengan mengetahui secara pasti masa dan suhu simpan yang optimal maka informasi tersebut dapat ditetapkan sebagai masa kadaluarsa bagi produk jus herbal yang diteliti ini.

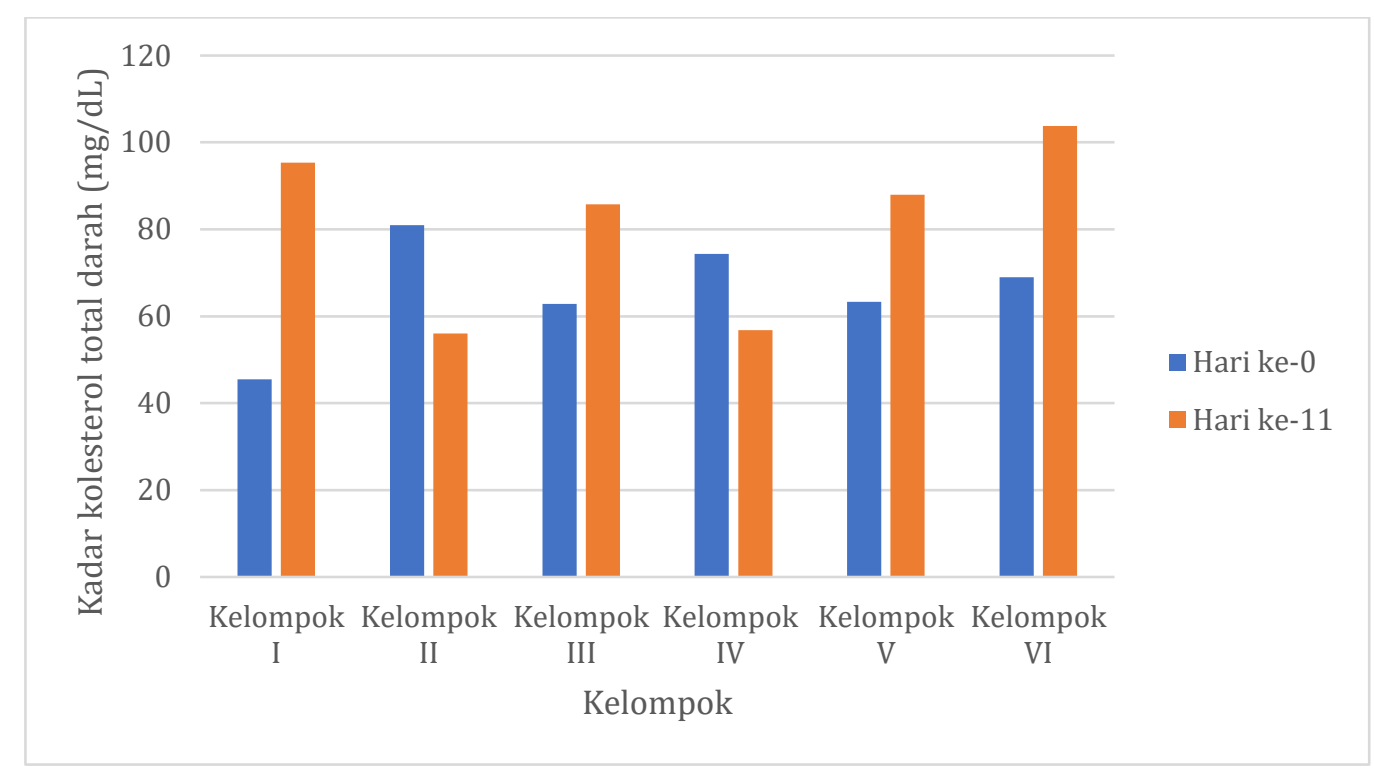

Gambar 1. Rerata kadar kolesterol total darah kelompok perlakuan sebelum dan setelah pemberian sediaan uji

Ket: kelompok I (NaCMC 0,5\%), kelompok II (jus herbal segar), kelompok III (jus herbal masa simpan 50 hari suhu kamar), kelompok IV (jus herbal masa simpan 50 hari suhu dingin), kelompok V (jus herbal masa simpan 100 hari suhu kamar), kelompok VI (jus herbal masa simpan 100 hari suhu dingin)

Dari hasil penelitian yang dilakukan, terjadi peningkatan rerata kadar kolesterol hari ke-11 pada kelompok yang hanya diberikan NaCMC 0,5\% (Gambar 1). Hal ini membuktikan bahwa terjadi peningkatan kadar kolesterol pada tikus percobaan yang diinduksi pakan tinggi lemak dan PTU. Hasil ini sejalan dengan penelitian-penelitian antihiperkolesterolemia yang menggunakan metode induksi yang sama (Probosari et al., 2011; Putu et al., 2010; Safitri et al., 2016).

Peningkatan kadar kolesterol juga terjadi di beberapa kelompok perlakuan lainnya yaitu kelompok III yang diberikan jus herbal dengan masa simpan 50 hari di suhu kamar, kelompok IV yang diberikan jus herbal dengan masa 100 hari pada suhu kamar dan suhu lemari pendingin 
(kelompok VI). Berdasarkan hasil analisa statistik One Way ANOVA yang dilanjutkan dengan uji Duncan, diketahui ketiga kelompok ini masih menunjukkan perbedaan yang signifikan terhadap kelompok kontrol negatif $(\mathrm{p}<0,05)$, yang artinya masih terdapat aktivitas penghambatan peningkatan kolesterol. Penurunan efektivitas ini dapat disebabkan masih terdapatnya kandungan air sari herbal masing-masing komponen sehingga reaksi penguraian tetap terjadi selama masa simpan. Namun, tidak terdapat perbedaan yang signifikan antara kadar kolesterol hari ke-11 ketiga kelompok tersebut $(\mathrm{p}>0,05)$. Hal ini berarti penurunan aktivitas ketiga kelompok perlakuan tersebut masih sebanding.

Kelompok tikus percobaan yang diberi jus herbal yang baru mengalami penurunan kadar kolesterol serta menunjukkan perbedaan yang signifikan terhadap kelompok kontrol negatif $(\mathrm{p}<0,05)$. Hasil tersebut mungkin disebabkan seluruh bahan herbal yang terdapat di dalam jus herbal berada dalam kondisi segar sehingga kandungan kimia yang ada di dalamnya masih dalam bentuk senyawa kimia asalnya yang menyebabkan efektivitas antihiperkolesterolemia tertinggi.

Penurunan kadar kolesterol juga diperlihatkan oleh pemberian jus herbal dengan masa simpan 50 hari pada suhu dingin (kelompok IV). Hasil analisis statistik menunjukkan tidak terdapat perbedaan yang signifikan dengan kelompok II. Hal ini membuktikan bahwa jus herbal yang disimpan selama 50 hari pada suhu dingin $\left(2-8^{\circ} \mathrm{C}\right)$ mampu mempertahankan keefektifannya sebagai antihiperkolesterolemia. Laju reaksi penguraian berjalan lebih lambat pada suhu dingin karena pemutusan ikatan kimia lebih sulit terjadi di suhu rendah. Ini disebabkan karena pada suhu rendah kecepatan partikel zat untuk bertabrakan lebih rendah. Peningkatan kecepatan reaksi bertambah seiring dengan bertambahnya suhu sesuai dengan hukum Arrhenius dimana molekul yang bereaksi harus memiliki energi yang cukup untuk mengatasi tolakan elektrostatik dan membutuhkan jumlah energi minimal untuk memecah ikatan kimia. Fenomena ini tidak terlihat pada kelompok yang diberikan jus herbal yang disimpan selama 100 hari pada suhu dingin (kelompok VI). Hal tersebut mungkin disebabkan peningkatan laju reaksi tidak hanya dipengaruhi suhu namun juga oleh proses enzimatis dan inaktivasi oleh mikroba (Peleg et al., 2012).

\section{Kesimpulan}

Jus herbal yang mengandung kombinasi bunga rosella, jahe merah, bawang putih, jeruk nipis, cuka apel dan madu menunjukkan efektivitas sebagai antihiperkolesterolemia pada tikus putih jantan setelah disimpan selama 50 hari dan 100 hari. Masa simpan dan suhu tidak mengurangi aktivitasnya.

Seminar Nasional Asosiasi Perguruan Tinggi Farmasi Indonesia (APTFI) III-Tantangan Pandemik (covid-19) dalam pembelajaran dan penelitian kefarmasian 16-20 Agustus 2021 (Virtual Conference) 


\section{Ucapan terimakasih}

Penelitian ini dapat terlaksana dengan bantuan hibah penelitian STIFI Bhakti Pertiwi.

\section{Daftar pustaka}

Asgary, S., Soltani, R., Zolghadr, M., Keshvari, M., \& Sarrafzadegan, N. (2016). Evaluation of The Effects of Roselle (Hibiscus sabdariffa L.) on Oxidative Stress and Serum Levels of Lipids, Insulin and hs-CRP in Adult Patients with Metabolic Syndrome: A Double-Blind Placebo-Controlled Clinical Trial. J Complement Integr Med, 13(2), 175-180.

Behesti, Z., Chan, Y. H., Nia, H. S., Hajihoseini, F., Nazari, R., Shaabani, M., \& Omran, M. T. S. ( 2012). Influence of Appel Cider Vinegar on Blood Lipids. Life Science Journal, 9(4).

Fitriani, M. (2018). TToksisitas Jus Herbal Kombinasi (Bawang Putih, Bunga Rosella, Cuka Apel, Jahe Merah, Jeruk Nipis dan Madu) terhadap Mencit Putih Jantan (Bachelor). STIFI Bhakti Pertiwi, Palembang.

Gebhardt, R. (1993). Multiple Inhibitory Effects of Garlic Extracts on Cholesterol Biosynthesis in Hepatocytes. Lipids, 28(7), 613-619.

Herpi, J. (2017). Efek Penurunan Kadar Kolesterol Total dan Peningkatan Cita Rasa Modifikasi Jus Herbal Kombinasi Buah Nanas, Bawang Putih,Jahe Merah, Jeruk Nipis, Cuka Apel dan Madu Pada Tikus Hiperkolesterol. (Bachelor). STIFI Bhakti Pertiwi, Palembang.

Juniati, H. (2017). Efek Penurunan Kadar Kolesterol Total Jus Herbal Modifikasi terhadap Tikus Putih Jantan Galur Wistar Hiperkolesterol yang Diinduksi Propiltiourasil. (Bachelor). STIFI Bhakti Pertiwi, Palembang.

Kemenkes. (2019). Laporan Nasional Riskesdas 2018. Jakarta: Badan Penelitian dan Pengembangan Kesehatan

Khan, Y., Khan, R., Afroz, S., \& Siddiq, A. (2010). Evaluation of Hypolipidemic Effect of Citrus Lemon. J. basic appl. Sci, 6, 39-43.

Murphy, S. L., Xu, J., \& Kochanek, K. D. (2012). Deaths: Preliminary data for 2010. National Vital Statistics Reports, 6(4).

Peleg, M., Normand, M. D., \& Corradini, M. G. (2012). The Arrhenius Equation Revisited. Critical Reviews in Food Science and Nutrition, 52(9), 830-851.

Probosari, E., W, H., \& Puruhita, N. (2011). Pemberian Teh Rosela (Hibiscus sabdariffa Linn), Simvastatin dan Profil Lipid Serta Serum ApoB pada Tikus Hiperkolesterolemia. Media Medika Indonesia 45(1), 41-48.

Putu, N., Chandra, S., \& Ayu, D. (2010). Uji Aktivitas Penurunan Kolesterol Produk Madu Herbal yang Beredar di Pasaran pada Tikus Putih Diet Lemak Tinggi. Jurnal Kimia, 4 (4), 377-384.

Risa, M. (2017). Efek Penurunan Kadar Kolesterol Total Jus Herbal Kombinasi Bawang Putih, Jahe Merah, Jeruk Nipis, Cuka Apel dan Madu terhadap Tikus Putih Hiperkolesterol yang Diinduksi Propil Tiourasil. (Bachelor). STIFI Bhakti Pertiwi, Palembang.

Safitri, D. N. F., Kurniati, S., Adharani, S. W., Suciati, S. W., \& Adnyana, I. K. (2016). The Study of Red Ginger Rhizomes Ethanol Extract (Zingiber officinale Roscoe var.Sunti Val.) on Hyperlipidemic Induced Rats. Pharmacology OnLine, 3, 15-21.

Tornado, S. (2019). Uji Toksisitas Subakut Jus Herbal Kombinasi (Bawang Putih, Bunga Rosella, Jahe Merah,Cuka Apel, Jeruk Nipis dan Madu) terhadap Fungsi dan Gambaran Histopatologi Ginjal Tikus Putih Jantan Galur Wistar. (Bachelor). STIFI Bhakti Pertiwi., Palembang.

Upia, D. (2017). Efek Penurunan Kadar Kolesterol Total Modifikasi Jus Herbal Kombinasi terhadap Tikus Putih Jantan Galur Wistar Hiperkolesterol yang Diinduksi Propiltiourasil. (Bachelor). STIFI Bhakti Pertiwi, Palembang.

WHO. (2020). Cardiovascular Disease. Retrieved from http://www.who.int/mediacentre/factsheets

Seminar Nasional Asosiasi Perguruan Tinggi Farmasi Indonesia (APTFI) III-Tantangan Pandemik (covid-19) dalam pembelajaran dan penelitian kefarmasian 16-20 Agustus 2021 (Virtual Conference) 